Proceedings of the 11th Polish-Japanese Joint Seminar on Micro and Nano Analysis, Gniew, September 11-14, 2016

\title{
The Effect of Severe Plastic Deformation and Heat Treatment on CuCrZr Alloys
}

\author{
A. KováČOvá ${ }^{a, *}$, T. KVAČKAJ ${ }^{a}$, R. KOČIŠKO ${ }^{a}$, L. DRAgOŠEK $^{b}$ \\ AND L. LITYŃSKA-DOBRZYŃSKA ${ }^{c}$ \\ ${ }^{a}$ Institute of Materials, Faculty of Metallurgy, Technical University of Košice, \\ Vysokoškolská 4, 04200 Košice, Slovakia \\ ${ }^{b}$ Institute of Materials and Machine Mechanics, Slovak Academy of Sciences - Inoval, \\ Priemyselná 12, 96501 Ladomerská Vieska — Žiar nad Hronom, Slovakia \\ ${ }^{c}$ Institute of Metallurgy and Materials Science of the Polish Academy of Sciences, \\ W.S. Reymonta 25, 30059 Kraków, Poland
}

\begin{abstract}
$\mathrm{CuCrZr}$ alloy was subjected to equal channel angular pressing method, belonging to the severe plastic deformation group, followed by heat treatment under different ageing conditions to optimize mechanical properties of the alloy. Before equal channel angular pressing, $\mathrm{CuCrZr}$ alloy was treated by solution annealing at temperature $1020^{\circ} \mathrm{C}$ for $1 \mathrm{~h}$. Afterwards, samples were pressed through an equal channel angular pressing die once at room temperature and subjected to artificial ageing under different conditions $\left(200,400,450,480^{\circ} \mathrm{C}\right.$ for $30,60,90,120$, $150 \mathrm{~min})$. Optimization of the $\mathrm{CuCrZr}$ alloy was done through the study of mechanical properties and microhardness as a function of ageing temperature and time considering the progress in microstructural/substructural features.
\end{abstract}

DOI: 10.12693/APhysPolA.131.1336

PACS/topics: 81.05.Bx, 81.40.Cd, 61.72.Ff

\section{Introduction}

A lot of current engineering applications require a sophisticated combination of physical and mechanical properties that can be quite controversial [1]. Severe plastic deformation (SPD) methods applied to metals enable specific microstructural and substructural features to be formed during the processing resulting in an unexpected combination of mechanical properties [2, 3]. Formation of such structures in materials causes microstructural refinement to the ultrafine-grained (UFG) or even nanocrystalline $(\mathrm{NC})$ area [4-6].

There are a number of SPD techniques such as high pressure torsion (HPT) [7], accumulative roll bonding (ARB) [8], equal channel angular rolling (ECAR) [9], but one of the most popular is equal channel angular pressing (ECAP) due to the equipment configuration simplicity. ECAP has been successfully used over the last decade to insure the ultrafine-grained structures in a wide range of ductile metals including pure $\mathrm{Cu}$ and $\mathrm{Cu}$ alloys $[4,5,10-13]$. Microstructure is refined to equiaxed subgrains/grains below $1 \mu \mathrm{m}$ under high strains through simple shear, accompanied with a significant increase of strength. During ECAP processing, boundaries with relatively low misorientation are formed by dislocations rearrangement at lower strain (dislocation cells substructure), which are progressively transformed to higher angle grain boundaries at higher strains $[5,14,15]$. At the

*corresponding author; e-mail: andrea.kovacova@tuke.sk same time ductility remains good for such heavily deformed $\mathrm{Cu}$ alloys [16].

$\mathrm{Cu}$ and $\mathrm{Cu}$ alloys are widely used because of their excellent electrical and thermal conductivities, outstanding resistance to corrosion, good strength and fatigue resistance, suitable ductility [17-20]. As the mechanical strength of pure $\mathrm{Cu}$ is limited for current engineering applications, $\mathrm{Cu}$ alloys as an example $\mathrm{CuCrZr}$ are attractive for a number of industrial fields. CuCrZr alloys are classified as precipitation-hardened $(\mathrm{PH})$ materials processed by heat treatment which are traditionally used in applications where a combination of high mechanical strength, heat resistance and electrical (or thermal) conductivity is demanded (electrodes for point welding, heat exchangers, etc.) [21-23]. It has to be mentioned that $\mathrm{CuCrZr}$ alloys are considered as a prime material for fusion reactors (international thermonuclear experimental reactor - ITER) [24, 25].

The aim of the study was to examine the mechanical behaviour of $\mathrm{CuCrZr}$ alloys processed by ECAP followed by ageing treatment focused on the study of microstructure.

\section{Experimental conditions}

The CuCrZr alloy supplied as a round bar of diameter $10 \mathrm{~mm}$ and length $100 \mathrm{~mm}(98.54 \mathrm{wt} \% \mathrm{Cu}$, $1.1 \mathrm{wt} \% \mathrm{Cr}, 0.043 \mathrm{wt} \% \mathrm{Zr}$ ) was used. Before ECAP processing, samples were given a solution annealing of $1020^{\circ} \mathrm{C}$ for $1 \mathrm{~h}$ and water quenched to form the single coarse-grained phase $(\mathrm{CG})$ with mechanical properties: yield strength $(\mathrm{YS})=144 \mathrm{MPa}$, ultimate tensile strength $(\mathrm{UTS})=277 \mathrm{MPa}$, reduction of area $(\mathrm{RA})=81 \%$. Consequently, the samples were processed once through an 
ECAP die (channel angle $\Phi=90^{\circ}, \Psi=32^{\circ}$ ) at ambient temperature. Heat treatment after ECAP processing was carried out at $200-480^{\circ} \mathrm{C}$ for $30-150 \mathrm{~min}$ followed by water quenching.

Mechanical properties were evaluated by uniaxial tensile testing on samples with a cylindrical gauge carried out at ambient temperature according to the EN ISO 6892-1. Two samples were tested for each material condition, confirming great reproducibility of both strength and reduction of area. Microhardness was measured in terms of HV0.1 using the Struers apparatus.

The microstructure was characterized by FEI transmission electron microscope Tecnai G2 (TEM) operating at $200 \mathrm{kV}$ equipped with high-angle annular dark field scanning transmission electron microscopy detector (HAADF-STEM) combined with energy dispersive X-ray (EDX) EDAX microanalysis. A Tenupol-5 double jet electropolisher was used for the thin foil preparation in electrolyte containing nitric acid and methanol (1:3), at the temperature of $-28^{\circ} \mathrm{C}$ and voltage of $20 \mathrm{~V}$.

\section{Results}

\subsection{Mechanical behaviour}

Results from engineering stress-strain measurements were presented in the graphical forms. Figure 1 shows the progress in YS and UTS on ageing time at different temperatures, as is seen the change in properties reproduces each other. According to Fig. 1, ageing at $200^{\circ} \mathrm{C}$ for $30,60,120$, and $150 \mathrm{~min}$ provides no significant changes in the strength properties compared to the initial state without ageing ( YS $=390 \mathrm{MPa}$, UTS $=392 \mathrm{MPa}$, $\mathrm{RA}=66 \%)$. Although it seems that at the temperature of $200{ }^{\circ} \mathrm{C}$ and $90 \mathrm{~min}$ ageing time, samples provide enhanced strength properties. Considering ageing
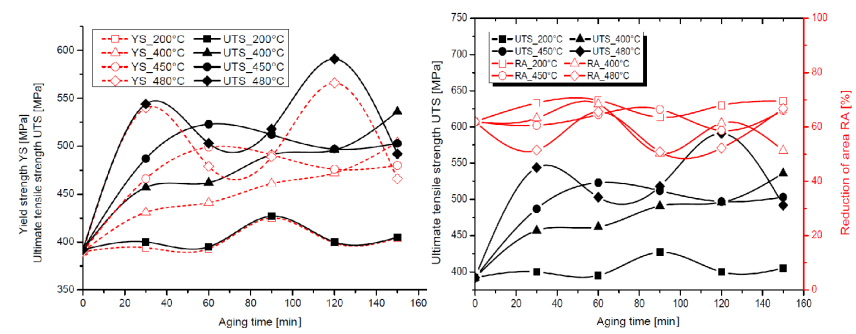

Fig. 1. Strength properties as a function of ageing time at different temperatures for $\mathrm{CuCrZr}$ alloy (compared to RA).

at $400^{\circ} \mathrm{C}$, strength properties gradually increased with longer ageing time, even progress in the properties was constant within the whole range of ageing time. On the other hand, ageing at $450{ }^{\circ} \mathrm{C}$ provides the growth in the strength compared to previous thermal processing but only up to $60 \mathrm{~min}$. Then longer annealing time brings the reduction of the strength in $\mathrm{CuCrZr}$ alloys. Considering ageing at $480{ }^{\circ} \mathrm{C}$ for $30 \mathrm{~min}$, the strength increased significantly even annealing for 120 min brings most visible growth in the strength. On the other hand, ageing at $480^{\circ} \mathrm{C}$ also provides rapid changes in the strength progress, heat treatment under such conditions could be quite unstable having a negative impact on the stability of material properties.

The RA changed from $81 \%$ to $62 \%$ after first ECAP pass (without ageing). Within the ageing, the values of RA were in the range of $\approx 50-70 \%$ depending on processing conditions (Fig. 1, right, compared to UTS).

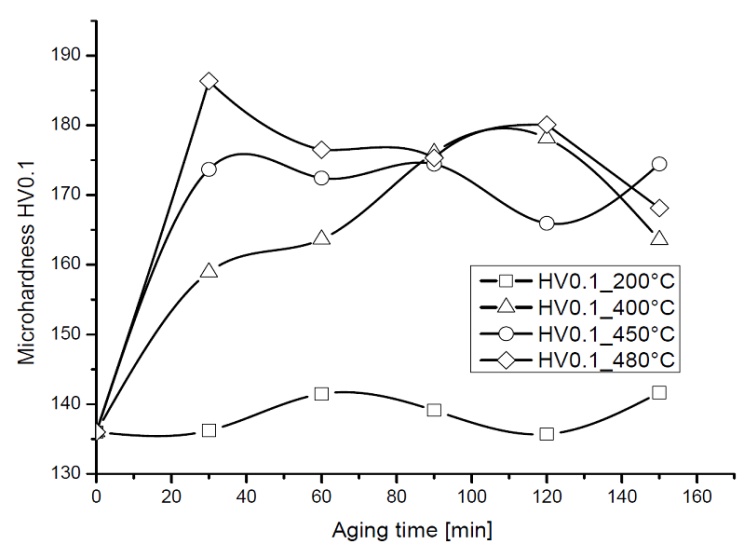

Fig. 2. Microhardness as a function of ageing temperature and time for $\mathrm{CuCrZr}$ alloys.

The results of microhardness measurements are summarized in Fig. 2. The initial microhardness of 50 HV0.1 has been measured for $\mathrm{CuCrZr}$ samples after solution annealing. After first ECAP pass (before ageing), the microhardness increased at $137 \mathrm{HV} 0.1$. Ageing at $200^{\circ} \mathrm{C}$ after ECAP processing does not provide any significant changes in the microhardness compared to a non-aged state. More visible increase in the microhardness was revealed at higher temperatures. At $400^{\circ} \mathrm{C}$, the microhardness increased with ageing time up to 120 min but for 150 min there was seen decrease in the values. Maximum microhardness of $186 \mathrm{HV} 0.1$ was obtained under processing conditions at $480^{\circ} \mathrm{C}$ for 30 min however further ageing provides the lower values. Ageing at $400^{\circ} \mathrm{C}$ is seen as a most stable in the progress of microhardness. According to Fig. 2, most significant increase of the microhardness within ageing is recognized in the first $30 \mathrm{~min}$. Similar progress was observed in the strength properties (Fig. 1). Moreover the next microhardness development $(60,90,120,150 \mathrm{~min}$.$) responds to the progress in me-$ chanical properties (YS, UTS). Strong peaks in Fig. 1 corresponding to the strength properties under ageing at $480^{\circ} \mathrm{C}$ for $120 \mathrm{~min}$ were not seen in the microhardness that could mean the mistake in measuring.

\subsection{Microstructure observations}

The microstructure of $\mathrm{CuCrZr}$ alloys after solution annealing and water quenching provides coarse grains with an average equivalent diameter of $50 \mu \mathrm{m}$. There were also visible numbers of twin boundaries [26].

In general, SPD methods insure significant microstructures refinement and already after the first pass of processing, re-arrangement in internal substructural features. Typical microstructure of $\mathrm{CuCrZr}$ alloys after solution annealing and 1 ECAP pass is shown in Fig. 3. 
Dislocation cells of different shapes with curved boundaries and low misorientation angles have been recognized (Fig. 3a). The first ECAP pass also provides huge increase in the dislocation density as is seen in Fig. 3b.

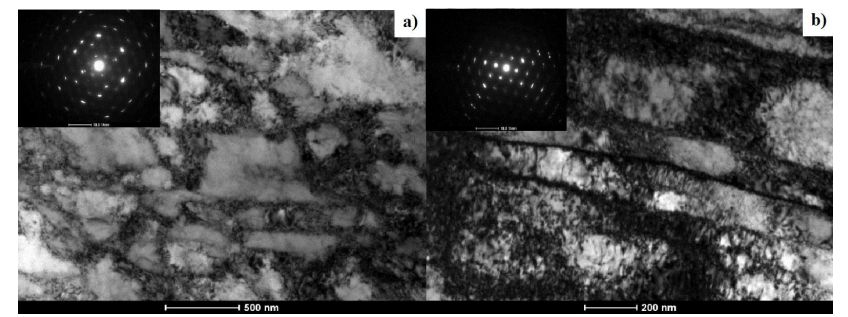

Fig. 3. Typical microstructure of $\mathrm{CuCrZr}$ alloys after 1 ECAP pass.

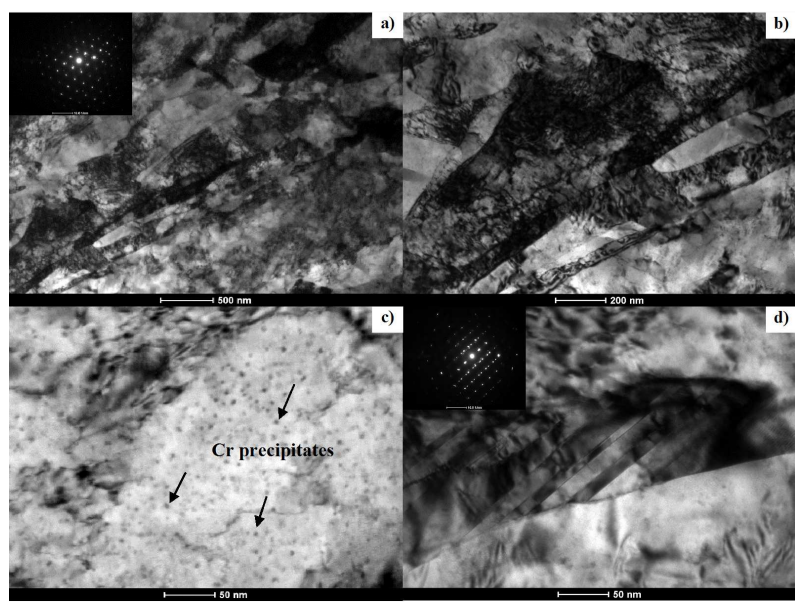

Fig. 4. Typical microstructure of $\mathrm{CuCrZr}$ alloys after $1 \mathrm{ECAP}$ pass and ageing at $480^{\circ} \mathrm{C}$ for $120 \mathrm{~min}$.
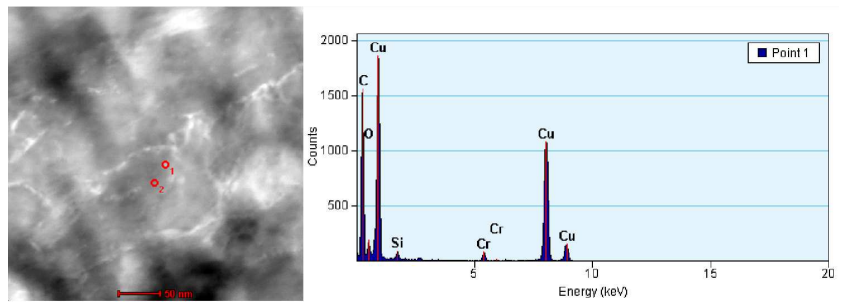

Fig. 5. HRTEM micrograph of $\mathrm{CuCrZr}$ alloys after 1 ECAP pass and ageing at $480^{\circ} \mathrm{C}$ for $120 \mathrm{~min}$ (a) and the typical EDXS qualitative analysis spectrum of phases (b).

The structure with very high density of dislocations is typical for SPD copper based alloys that exhibit rather low stacking fault energy (SFE) [27]. As a result, dislocations are separating during plastic deformation which induces more dislocation tangles. They baffle dislocations to move and with further deformation they behave like a dislocation sources which leads to accrue the dislocations. As a result the morphology with high density of dislocations is obtained [27].
After ageing at $480^{\circ} \mathrm{C}$ for $120 \mathrm{~min}$ the structure of $\mathrm{Cu}$ CrZr alloys remains without any significant grain coarsening (Fig. 4). As is seen in Fig. 4a, grain boundaries become more sharp, meaning recovery occurring in the grains boundaries and their vicinity. Besides, the dislocation density is still high (Fig. 4b), indicating that dislocations are strongly pinned. A lot of $\mathrm{Cr}$-rich precipitations in the grain interior and narrow annealing twins were also recognized in the structure of $\mathrm{CuCrZr}$ alloys after the ageing (Fig. 4c,d). Typical EDXS qualitative analysis spectrum of the chromium-rich phase from HRTEM micrograph is shown in Fig. 5 (there are visible copper spectrum peaks and chromium peaks).

\section{Discussion}

In the early stage of ECAP processing, the microstructure typically consists of initial grains with a high density of dislocations in their interior, which are arranged to tangled dislocations (cells) and to dense dislocation walls (DDWs). DDWs with low misorientation are classified as geometrically necessary boundaries since they participate in accommodation of lattice rotations in the adjoining volume [28]. Moreover, DDWs are in a nonequilibrium state as they contain a high density of extrinsic dislocations. Such specific micro/substructural features which are being formed in the early stage of ECAP processing can also assist in further age hardening and controlling how the precipitates would decorate the microstructure. Besides, alloying of pure metals results in significant increase of their mechanical strength controlling by microstructure, of which grain size, morphology of second phases, and their distribution as well as dislocation structure, are the most important parameters.

In this study, the ageing process at $400,450,480^{\circ} \mathrm{C}$ for 30 min applied to the supersaturated $\mathrm{CuCrZr}$ alloy after one ECAP pass increased its strength and microhardness considerably. This is mainly due to the formation of the fine and coherent nanosized Cr-rich particles, which precipitate from supersaturated copper matrix [29]. The microhardness reached the peak value of 185 HV0.1 at $480^{\circ} \mathrm{C}$ after $30 \mathrm{~min}$, which can be attributed to the precipitation of $\mathrm{Cr}$ that are fully coherent with the $\mathrm{Cu}$ matrix and have the same fcc lattice parameter, as reported by Liu et al. [21] who suggest fully coherent Cr-rich precipitates at $480^{\circ} \mathrm{C}$ after $60 \mathrm{~min}$. Though, this behavior appears to be due to the enhanced kinetics of precipitation as a result of ECAP processing. During ageing, the previously formed dislocations within ECAP process interact with the stress fields around these coherent particles and thus the strength and hardness increased considerably and moreover faster as such dislocations are in a nonequilibrium state [29].

Precipitation process during ageing treatment at $400{ }^{\circ} \mathrm{C}$ in $\mathrm{CuCrZr}$ alloys after one ECAP pass provides the constant increase in the strength in a whole range of ageing time. Considering ageing at 450 and $480^{\circ} \mathrm{C}$, there are obvious significant differences in properties depending on ageing time. According to the [29], ageing after SPD processing has no significant effect on the grain 
morphology and size, and no recrystallization is evident in the UFG microstructure. However, this process leads to formation of precipitates inside the UFG microstructure, and decreases the dislocation density and elastic stresses especially at the grain/subgrain boundaries of the UFG microstructure due to the recovery processes activated during ageing. Also according to the [29], the softening (recovery) process during ageing coming from re-arrangement of dislocations in UFG CuCrZr alloy aged at $450^{\circ} \mathrm{C}$ for $1 \mathrm{~h}$. Gao et al. [30] claimed in binary $\mathrm{Cu}-\mathrm{Cr}$ alloy that if precipitation takes place earlier than recrystallization at relatively low temperatures or prestrains, the precipitates have enough time to grow significantly and retard the rearrangement of dislocations, which in turn delays the onset of recrystallization. Also, the recrystallization would be inhibited to a great extent because of the precipitation in the deformed UFG microstructure.

\section{Conclusions}

The effect of ECAP followed by further ageing on the mechanical properties, microhardness and microstructure of $\mathrm{CuCrZr}$ alloy was investigated. The main findings can be summarized as below:

1. High strength properties and microhardness can be obtained in the alloy processed through an ECAP method followed by ageing. The most significant increase in the strength and microhardness is recognized in the first 30 min of heat treatment. Maximum microhardness of 186 HV0.1 was obtained under processing conditions at $480^{\circ} \mathrm{C}$ for $30 \mathrm{~min}$.

2. Microstructure of the alloy after solution annealing and ECAP processing is dramatically changed already in the first pass. Dislocation cells of different shapes with curved boundaries and low misorientation angles as well as a huge increase in the dislocation density were observed in the microstructure of $\mathrm{CuCrZr}$ alloys. Ageing at $480^{\circ} \mathrm{C}$ for $120 \mathrm{~min}$ provides any significant grain coarsening. Grain boundaries become more sharp, a lot of precipitations in the grain interior and narrow annealing twins were also recognized in the structure of $\mathrm{Cu}-$ CrZr alloys.

\section{Acknowledgments}

This work was financially supported by the VEGA 1/0325/14 project.

\section{References}

[1] R.Z. Valiev, A.P. Zhilyaev, T.G. Langdon, Bulk Nanostructured Materials. Fundamental and Applications, TMS-Wiley, Hoboken (NJ) 2014.

[2] M.Y. Murashkin, I. Sabirov, X. Sauvage, R.Z. Valiev, J. Mater. Sci. Lett. 51, 33 (2015)).

[3] G. Purcek, O. Saray, O. Kul, I. Karaman, G.G. Yapici, M. Haouaoui, H.J. Maier, Mater. Sci. Eng. A 517, 97 (2009)).
[4] T. Kvackaj, A. Kovacova, M. Kvackaj, I. Pokorny, R. Kocisko, T. Donic, Mater. Lett. 64, 2344 (2010)).

[5] T. Kvackaj, A. Kovacova, R. Kocisko, J. Dutkiewicz, L. Litynska-Dobrzynska, J. Kansy, Metall. Mater. 52, 337 (2014)).

[6] R. Valiev, Nature Mat. 3, 511 (2004).

[7] K.X. Wei, W. Wei, I.V. Alexandrov, Q.B. Du, J. Hu, Adv. Mater. Res. 391-392, 385 (2012)).

[8] I. Altenberger, H.A. Kuhn, M. Gholami, M. Mhaede, L. Wagner, Metals 5, 763 (2015)).

[9] T. Kvackaj, A. Kovacova, M. Kvackaj, R. Kocisko, L. Litynska-Dobrzynska, V. Stoyka, M. Mihalikova, Micron 43, 720 (2012)).

[10] M.H. Shih, C.Y. Yu, P.W. Kao, C.P. Chang, Scr. Mater. 45, 793 (2001)).

[11] K.X. Wei, W. Wei, F. Wang, Q.B. Du, I.V. Alexandrov, J. Hu, Mater. Sci. Eng. A 528, 1478 (2011)).

[12] A. Vinogradov, V. Patlan, Y. Suzuki, K. Kitagawa, V.I. Kopylov, Acta Mater. 50, 1639 (2002)).

[13] S.J. Huang, V.I. Semenov, E.I. Fakhretdinova, A.G. Raab, Acta Metall. Slov. 20, 295 (2014)).

[14] A. Mishra, B.K. Kad, F. Gregori, M.A. Meyers, Acta Mater. 55, 13 (2007)).

[15] A. Vinogradov, T. Ishida, K. Kitagawa, V.I. Kopylov, Acta Mater. 53, 2181 (2005)).

[16] R.Z. Valiev, T.G. Langdon, Prog. Mater. Sci. 51, 881 (2006).

[17] A. Kauffmann, D. Geissler, J. Freudenberger, Mater. Sci. Eng. A 651, 567 (2016)).

[18] H.C. Chen, G.J. Bi, M.L.S. Nai, J. Wei, J. Mater. Process. Tech. 216, 287 (2015).

[19] K. Valdes Leon, M.A. Munoz-Morris, D.G. Morris, Mater. Sci. Eng. A 536, 181 (2012)).

[20] G. Purcek, H. Yanar, M. Demirtas, Y. Alemdag, D.V. Shangina, S.V. Dobatkin, Mater. Sci. Eng. A 649, $114(2016))$.

[21] Q. Liu, X. Zhang, Y. Ge, J. Wang, J.Z. Cui, Metall. Mater. Trans. A 37, 3233 (2006)).

[22] Z. Li, Z.Y. Pan, Y.Y. Zhao, Z. Xiao, M.P. Wang, J. Mater. Res. 24, 2123 (2009)).

[23] P. Liu, B.X. Kang, X.G. Cao, J.L. Huang, H.C. Gu, J. Mater. Sci. 35, 1691 (2000)).

[24] V.R. Barabash, G.M. Kalinin, S.A. Fabritsiev, S.J. Zinkle, J. Nucl. Mater. 417, 904 (2011)).

[25] P. Lorenzetto, A. Peacock, I. Bobin-Vastra, L. Briottet, P. Bucci, G. Dell'Orco, K. Ioki, M. Roedig, P. Sherlock, Fusion Eng. Des. A 81, 355 (2006)).

[26] M. Kulczyk, B. Zysk, M. Lewandowska, K.J. Kurzydlowski, Phys. Status Solidi A 207, 5 (2010)).

[27] M. Lipinska, P. Bazarnik, M. Lewandowska, IOP Conf. Ser. Mater. Sci. Eng. 63, 012119 (2014).

[28] R. Kuzel, M. Janecek, Z. Matej, J. Cizek, M. Dopita, O. Srba, Metall. Mater. Trans. A 41, 1174 (2010).

[29] G. Purcek, H. Yanar, O. Saray, I. Karaman, H.J. Maier, Wear 311, 149 (2014).

[30] N. Gao, E. Huttunen-Saarivirta, T. Tiainen, M. Hemmila, Mater. Sci. Eng. A 342, 270 (2003). 